\title{
KARAKTERISTIK PENDERITA KANKER SERVIKS STADIUM LANJUT DI BLU RSUP PROF. DR. R. D. KANDOU PERIODE 1 JANUARI 2010 - 31 DESEMBER 2011
}

\author{
${ }^{1}$ Raymond Rarung \\ ${ }^{2}$ Maria Loho \\ ${ }^{2}$ Eddy Suparman
}

\author{
${ }^{1}$ Kandidat Skripsi Fakultas Kedokteran Universitas Sam Ratulangi Manado \\ ${ }^{2}$ Bagian Obstetri dan Ginekologi Fakultas Kedokteran Universitas Sam Ratulangi \\ email: emon_jrr@yahoo.com
}

\begin{abstract}
Abstrak: Di dunia kanker serviks menempati urutan kedua terbanyak setelah keganasan payudara, dan kira-kira $10 \%$ dari seluruh penyakit keganasan pada wanita. Diperkirakan diseluruh dunia ditemukan 500.000 kasus baru setiap tahunnya. Kanker ini masih merupakan penyebab utama kematian dari seluruh kanker pada wanita terutama di usia produktif. Di negara berkembang termasuk Indonesia masih menempati urutan teratas dari seluruh kanker pada wanita. Di Indonesia sampai saat ini kanker serviks masih merupakan masalah kesehatan pada wanita. Pada umumnya penyakit ini dirawat kira-kira sekitar $70-75 \%$ sudah berada pada stadium lanjut dengan tingkat kematian yang sangat tinggi. Tujuan penelitian ini adalah untuk mengetahui berapa angka kejadian kanker serviks stadium lanjut di BLU RSUP Prof. Dr. R. D. Kandou Manado.
\end{abstract}

Kata Kunci: Usia Produktif, Kanker Serviks, Stadium Lanjut, dan Deteksi Dini.

\begin{abstract}
Worldwide cervical cancer ranks second highest after breast malignancies, and approximately $10 \%$ of all malignant disease in women. Worldwide estimated 500,000 new cases are found each year. Cervical cancer is still the leading cause of all cancer deaths in women, especially in productive age. In developing countries such as Indonesia still ranks highest of all cancers in women. In Indonesia today cervical cancer is still a health problem in women. In general, the disease is treated roughly about $70-75 \%$ are already at an advanced stage with a very high mortality rate. The purpose of this study was to determine how the incidence of advanced cervical cancer in BLU RSUP Prof. Dr. R. D. Kandou Manado.
\end{abstract}

Keywords: Productive Age, Cervical Cancer, Advanced Stage, and Early Detection.

Kanker serviks adalah keganasan yang tumbuh pada awalnya di daerah SSK (sambungan skuamo kolumner) dari serviks. ${ }^{1}$ Didunia kanker serviks menempati urutan kedua terbanyak setelah keganasan payudara, dan kira-kira $10 \%$ dari seluruh penyakit keganasan pada wanita. ${ }^{2}$

Diperkirakan diseluruh dunia ditemukan 500.000 kasus baru setiap tahunnya. Kanker ini masih merupakan penyebab utama kematian dari seluruh kanker pada wanita terutama di usia produktif. $^{3}$ Pada umumnya penyakit ini dirawat kira-kira sekitar 70-75\% sudah berada pada stadium lanjut dengan tingkat kematian yang sangat tinggi. Pada tahun 2007 diperkirakan pada setiap hari ditemukan 41 kasus baru dan kira-kira 20 kasus kematian. ${ }^{4}$

Di Manado, berdasarkan kasus yang dirawat di RSUP Prof. Dr. R. D. Kandou Malalayang Manado pada beberapa tahun terakhir ini ditemukan kira-kira 70-80\% sudah berada pada stadium lanjut. ${ }^{5}$ 
Berdasarkan hal diatas tadi maka saya ingin mengetahui lagi bagaimana karakteristik kanker serviks stadium lanjut yang dirawat di RSUP Prof. Dr. R. D. Kandou dari 1 januari 2010-31 desember 2011.

\section{METODE PENELITIAN}

\section{Jenis penelitian}

Jenis penelitian yang dilakukan adalah Retrospektif Deskriptif.

\section{Tempat dan waktu penelitian}

Penelitian ini mengambil tempat di bagian Obstetri dan Ginekologi BLU RSUP. Prof. Dr. R. D. Kandou Manado dan penelitian ini dilakukan oleh penulis selama 2 tahun terhitung sejak 1 Januari 2010 - 31 Desember 2011.

\section{Materi penelitian}

Materi penelitian ini diambil dari catatan medik penderita kanker serviks stadium lanjut yang dirawat di bagian Obstetri dan Ginekologi BLU RSUP. Prof. Dr. R. D. Kandou Manado selama periode 1 Januari 2010 sampai dengan 31 Desember 2011.

\section{Variabel penelitian}

Variabel yang diamati: umur, stadium klinik, paritas, usia pertama kali menikah , pendidikan ibu, pekerjaan ibu, pekerjaan suami dan penanganan.

\section{HASIL DAN BAHASAN}

Tabel 1. Distribusi kanker serviks stadium lanjut menurut umur

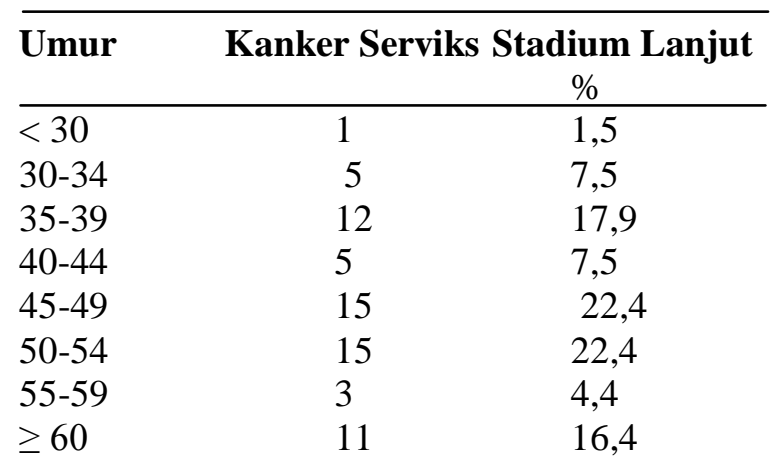

Total 67 100

Dari 67 kasus kanker serviks yang ditemukan dan dikelompokan berdasarkan umur sesuai Tabel 1 ternyata didapatkan kelompok umur 45-49 dan 50-54 tahun adalah yang terbanyak, yaitu masing-masing 15 kasus (22,4\%), atau 44,8\% dari total kasus. Hal ini sesuai kepustakaan yang ada, dimana mengatakan bahwa umur rata-rata kanker serviks stadium lanjut adalah 51 tahun dan ada kecenderungan ditemukan pada umur yang lebih muda. ${ }^{6}$ Seperti pada penelitian ini telah ditemukan pula 17 kasus (25,4\%) stadium lanjut pada kelompok umur 30-39 tahun. Hal ini memperlihatkan bahwa wanita-wanita yang berusia muda pun telah rentan untuk menderita kanker leher rahim sampai pada stadium lanjut.

Tabel 2. Distribusi kanker serviks stadium lanjut menurut stadium klinik

\begin{tabular}{lcc}
\hline Stadium Klinik & Kanker Serviks & $\begin{array}{c}\text { Stadium Lanjut } \\
\mathbf{\%}\end{array}$ \\
\hline IIB & 38 & 56,7 \\
IIIA & 10 & 14,9 \\
IIIB & 16 & 23,9 \\
IVA & 3 & 4,5 \\
IVB & 0 & 0 \\
Total & 67 & 100 \\
\hline
\end{tabular}

Pada Tabel 2 memperlihatkan bahwa kasus kanker serviks stadium lanjut paling banyak ditemukan pada stadium klinik IIB yaitu sebanyak 38 kasus (56,7\%). Tingginya kasus yang dirawat telah mencapai stadium lanjut ini juga menggambarkan bahwa usaha penapisan dan penanggulangan kanker leher rahim masih belum berhasil walaupun program pap smear bahkan IVA ( Inspeksi Visual dengan Asam Asetat) telah dijalankan bahkan diprogramkan oleh pemerintah dan departemen terkait serta melibatkan perguruan tinggi, masyarakat dan organisasi-organisasi sosial lain termasuk organisasi kewanitaan. Hal ini juga kemungkinan besar ditunjang oleh pengetahuan dan kepedulian dari ibu-ibu 
untuk melakukan pemeriksaan secara teratur dan berkesinambungan.

Tabel 3. Distribusi kanker serviks stadium lanjut menurut paritas

\begin{tabular}{lcc}
\hline Paritas & Kanker Serviks & $\begin{array}{c}\text { Stadium Lanjut } \\
\text { \% }\end{array}$ \\
\hline $\mathrm{P}_{1}$ & 5 & 7,5 \\
$\mathrm{P}_{2}$ & 18 & 26,9 \\
$\mathrm{P}_{3}$ & 20 & 29,8 \\
$\geq \mathrm{P}_{4}$ & 24 & 35,8 \\
Total & 67 & 100 \\
\hline
\end{tabular}

Berdasarkan jumlah paritas yang terpapar pada Tabel 3 ternyata ibu dengan anak $\geq 4(\mathrm{P} \geq 4)$ terbanyak menderita kanker serviks stadium lanjut, yaitu sebanyak 24 kasus (35,8\%). Hasil yang ditemukan ini tidak berbeda dengan kepustakaan dimana menyatakan bahwa makin tinggi paritas maka makin besar pula kecenderungan untuk menderita kanker leher rahim. Tingginya paritas bukan merupakan penyebab tetapi hanya sebagai salah satu faktor risiko untuk terinfeksi virus HPV risiko tinggi. $^{7}$

Tabel 4. Distribusi kanker serviks stadium lanjut menurut usia pertama kali menikah

\begin{tabular}{lcc}
\hline $\begin{array}{l}\text { Usia Pertama } \\
\text { Kali Menikah }\end{array}$ & Kanker Serviks & $\begin{array}{c}\text { Stadium Lanjut } \\
\mathbf{\%}\end{array}$ \\
\hline$<15$ & 3 & 6,8 \\
$15-19$ & 18 & 40,9 \\
$20-24$ & 12 & 27,3 \\
$25-29$ & 6 & 13,6 \\
$\geq 30$ & 5 & 11,4 \\
Total & 44 & 100
\end{tabular}

ket: 23 kasus tidak ada datanya

Pada Tabel 4 memperlihatkan bahwa ibu yang menikah pada kelompok umur 15 19 tahun terbanyak menderita kanker serviks stadium lanjut, yaitu sebanyak 18 kasus (40,9\%) dari 44 kasus yang terdata. Telah ditemukan 23 kasus tidak menyertakan keterangan tentang perkawinan. Hasil ini dapat menggambarkan bahwa hubungan seks/sanggama pertama kali dilakukan lebih dini yaitu dibawah 20 tahun adalah merupakan risiko mendapatkan kanker leher rahim. Nampak jelas bahwa sanggama usia muda merupakan faktor risiko untuk terpaparnya infeksi virus HR-HPV yang menyebabkan kanker leher rahim. ${ }^{7}$

Tabel 5. Distribusi kanker serviks stadium lanjut menurut pendidikan Ibu

\begin{tabular}{lcc}
\hline $\begin{array}{l}\text { Pendidikan } \\
\text { Ibu }\end{array}$ & Kanker Serviks & $\begin{array}{c}\text { Stadium Lanjut } \\
\mathbf{\%}\end{array}$ \\
\hline SD & 19 & 28,4 \\
SMP & 10 & 14,9 \\
SMA & 35 & 52,3 \\
D1-D3 & 1 & 1,5 \\
S1 & 2 & 2,9 \\
Total & 67 & 100 \\
& & \\
\hline
\end{tabular}

Pada Tabel 5 memperlihatkan bahwa ibu yang berpendidikan SMA merupakan yang terbanyak menderita kanker serviks stadium lanjut, dengan jumlah penderita sebanyak 35 kasus (52,3\%). Hal ini memperlihatkan bahwa walaupun ibu-ibu berpendidikan SMA tidak memberi jaminan untuk lebih memahami atau mengerti tentang pentingnya kesehatan terutama untuk kesehatan pribadi sendiri. Sehingga kepedulian untuk terhindar dari penyakit termasuk kanker leher rahim nampaknya masih tinggi. Hal ini juga tidak terlalu sesuai dengan kepustakaan yang menyatakan bahwa semakin rendah pendidikan makin tinggi peluang untuk menderita kanker serviks. ${ }^{8}$

Tabel 6. Distribusi kanker serviks stadium lanjut menurut pekerjaan Ibu

\begin{tabular}{lcc}
\hline $\begin{array}{l}\text { Pekerjaan } \\
\text { Ibu }\end{array}$ & Kanker Serviks Stadium Lanjut \\
& & \\
\hline IRT & 41 & 61,2 \\
Swasta & 13 & 19,4 \\
PNS & 8 & 11,9 \\
Petani & 5 & 7,5 \\
Total & 67 & 100 \\
\end{tabular}


Berdasarkan Tabel 6 didapatkan ternyata ibu yang bekerja sebagai IRT (ibu rumah tangga) adalah terbanyak menderita kanker serviks stadium lanjut, yaitu 41 kasus (61,2 \%). Kedua terbanyak adalah kelompok pekerjaan sebagai swasta yaitu sebanyak 13 kasus ( 19,4\% ). Hasil ini tidak memperlihatkan secara jelas sebagai faktor risiko untuk terjadinya kanker leher rahim. Walaupun pekerjaan sebagai IRT harus diteliti lagi lebih lanjut, demikian juga faktor pekerjaan sebagai swasta harus ditelusuri lagi lebih saksama. Kemungkinan besar ibu-ibu tidak menjelaskan secara lebih transparan bidang pekerjaannya.

Tabel 7. Distribusi kanker serviks stadium lanjut menurut pekerjaan suami

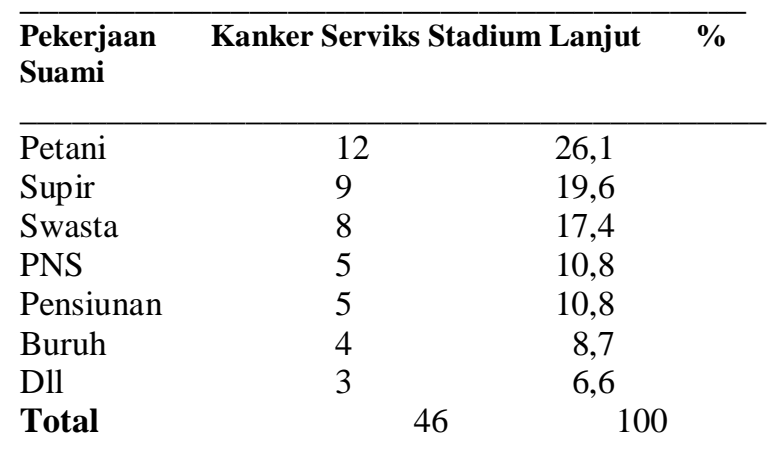

ket: 21 kasus tidak ada datanya

Pada Tabel 7 memperlihatkan bahwa pekerjaan suami sebagai petani adalah yang terbanyak istrinya menderita kanker leher rahim yaitu 12 kasus (26,1\%) dari 46 kasus yang terdata. Sebanyak 21 kasus tidak disertai dengan keterangan tentang pekerjaan suami. Kelompok pekerjaan kedua terbanyak adalah sebagai supir yaitu 9 kasus (19,6\%) dari 46 yang terdata. Kelompok petani tidak merupakan faktor risiko tetapi kelompok supir dapat dikategorikan sebagai faktor risiko untuk kecenderungan terjangkitnya infeksi HPV kepada istri.?

Tabel 8. Distribusi Kanker Serviks Stadium Lanjut Menurut Penanganan

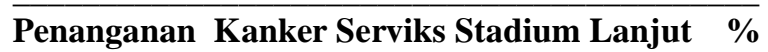

Kemoterapi

21

31,3
Paliatif:

$\begin{array}{lcc}\text { - Transfusi darah } & 30 & 44,8 \\ \text { - Perbaikan KU } & 16 & 23,9 \\ \text { Total } & 67 & 100\end{array}$

Pada tabel 4.8 paling banyak adalah kelompok yang dilakukan tindakan transfusi darah yaitu sebanyak 30 kasus (44,8\%) diikuti oleh pengobatan kemoterapi sebanyak 21 kasus (31,3\%). Hal ini memperlihatkan bahwa penanganan kasus stadium lanjut terbanyak adalah penanganan secara paliatif saja yaitu sebanyak 46 kasus $(68,7 \%)$. Selain transfusi darah penanganan yang diberikan untuk memperbaiki keadaan umum dari penderita. Dari 67 kasus stadium lanjut yang dirawat hanya 21 kasus (31,3\%) diberikan kemoterapi berbasis Cisplatinum (PVB). Kurangnya kasus stadium lanjut yang diberikan pengobatan dengan kemoterapi ini kemungkinan besar oleh karena tidak mampu untuk membeli obat kemoterapi ini karena mahal. Pengobatan yang terbaik pada stadium lanjut sebenarnya meliputi 2 modal utama yaitu radiasi lengkap dan kemoterapi.

\section{SIMPULAN}

Dari hasil penelitian secara retrospektif deskriptif terhadap karakteristik kanker serviks stadium lanjut di BLU RSUP Prof. Dr. R. D. Kandou Manado periode 1 Januari 2010 - 31 Desember 2011 diperoleh angka kejadian kanker serviks stadium lanjut yaitu sebanyak 67 kasus. Didapatkan kelompok umur 45-49 dan 50-54 tahun adalah yang terbanyak, yaitu masing-masing 15 kasus $(22,4 \%)$, atau $44,8 \%$ dari total kasus. Stadium klinik yang terbanyak adalah IIB yaitu 38 kasus (56,7\%). Wanita yang menikah pada kelompok umur 15 - 19 tahun adalah yang terbanyak menderita kanker serviks stadium lanjut, yaitu sebanyak 18 kasus (40,9\%) dari 44 kasus yang terdata dan wanita yang melakukan sanggama pertama kali pada umur $<20$ tahun sebesar 21 kasus (47,7\%) dari 44 kasus yang terdata, begitu juga dengan jumlah paritas $\geq 4$ adalah yang terbanyak menderita kanker serviks yaitu 24 kasus (35,8\%). Wanita yang menderita kanker serviks stadium lanjut terbanyak memiliki pendidikan terakhir 
SMA yaitu 35 kasus (52,3\%) dengan pekerjaan sebagai ibu rumah tangga sebanyak 41 kasus (61,2 \%) dan pendidikan suami sebagai petani yaitu sebanyak 12 kasus $(26,1 \%)$ dari 46 kasus yang terdata. Tindakan transfusi darah adalah yang terbanyak dilakukan yaitu 30 kasus (44,8\%).

\section{SARAN}

- Disarankan untuk melengkapi administrasi khususnya catatan medik penderita dengan mengikuti ICD X/ICD IX karena pada saat penulis melakukan penelitian ditemukan beberapa data yang tidak lengkap.

- Melakukan pemeriksaan standar kriteria umum kesehatan reproduksi wanita (contohnya pap smear) terutama pada wanita dalam masa reproduksi ke dokter spesialis atau ke klinik Rumah Sakit untuk deteksi dini terjadinya kemungkinan terburuk dari kanker serviks.

- Bila mungkin fasilitas radiasi dapat segera diadakan.

\section{DAFTAR PUSTAKA}

1. Hartati N, Andrijono, Suheimi HK. Cegah dan Deteksi Kanker Serviks. Surabaya: Elex Media Komputindo, 2010; p.2-9.

2. Gershenson DM, Mcguire WP, Gore M, Quinn MA, Thomas G. Gynecologic Cancer: Controversies in Management. New York: Elsevier Churchill Livingstone, 2004; p.4-22.

3. Perez CA, Grigsby PW, Mutch DG, Chao KS, Basil J. In: Rubin P, editor. Clinical Oncology: A multidisciplinary Approach for Physicians and Students. $8^{\text {th }}$ ed Philadelphia USA: W.B. Saunders Company, 2001; p.462-7.

4. Rasjidi I, Sulistiyanto H. Vaksin Human Papilloma Virus dan Eradikasi Kanker Mulut Rahim. Jakarta: Sagung Seto, 2007; p.1-36.

5. Rohan TE, Shah KV. Cervical Cancer: From Etiology to Prevention. Netherlands: Kluwer Academic Publishers, 2004; p.61-7.

6. Berek JS, Hacker NF. Practical Gynecologic Oncology (4 $4^{\text {th }}$ Ed). Philadelphia USA: Lippincott Williams \& Wilkins, 2005; p.337-42.

7. Rasjidi I. Deteksi Dini \& Pencegahan Kanker pada Wanita. Jakarta: Sagung Seto, 2009, p.97-143.

8. Andrijono. Kanker Serviks. Jakarta: Divisi Onkologi Departemen Obstetri - Ginekologi Fakultas Kedokteran Universitas Indonesia, 2009; p.1-47. 